\title{
How Millennials Can Promote Social Harmony through Intercultural Communication at Higher Education
}

DOI: https://doi.org/10.47175/rissj.v3i1.398

\section{| Sukardi Weda1, ${ }^{1,}$ | Fathu Rahman ${ }^{2}$ | Iskandar Abdul Samad ${ }^{3}$ | | Fahmi Gunawan ${ }^{4}$ | Siti Sarah Fitriani ${ }^{5}$ |}

\author{
${ }^{1}$ Faculty of Languages and \\ Literature, Universitas Negeri \\ Makassar, Indonesia \\ ${ }^{2}$ English Department, Faculty \\ of Cultural Sciences, \\ Hasanuddin University, \\ Makassar, Indonesia \\ 3,5English Department \\ Education, Faculty of Teacher \\ Training and Education, Syiah \\ Kuala University, Kota Banda \\ Aceh, Aceh, Indonesia
}

${ }^{4}$ Department of Arabic Language Education, IAIN Kendari, Kendari

*sukardi.weda@unm.ac.id

\begin{abstract}
Intercultural communication is a fundamental key to build social harmony. This study aims to investigate students' perceptions on promoting social harmony through intercultural communication practices in Indonesia as a multi ethnic and multi culture country. It also investigates the elements that are needed to build social harmony in Indonesia, so that the government of the Republic of Indonesia could take the study report as a reference for formulating policy in social development in Indonesia. This study uses a mix-methods research design (quantitative-qualitative) with a descriptive statistical paradigm that describes the mean, SD, percentage, weight, and rank followed by a detailed explanation of the statements given by the subject. The subjects of this study were students of the Department of English, Faculty of Language and Literature, Universitas Negeri Makassar for the 2019/2020 academic year. The research instrument was a closed and open questionnaire. Therefore, this study indicates that: (1) The results show that several positive behaviors of people from different ethnic groups need to be encouraged, for example tolerance, mutual understanding, mutual respect, not demeaning different tribes, and (2) The results also show that positive stereotypes and inclusive behavior are very important in building social harmony and peace in multi-ethnic countries. The implication of this research is to build social harmony in Indonesia as a multiethnic country that is hampered by hundreds of ethnic groups, cross-cultural competence (CCC) and intercultural communication are very important among Indonesian people, especially for millennials as important elements of social life.

KEYWORDS

millennials; social harmony; intercultural communication
\end{abstract}

\section{INTRODUCTION}

Almost all countries in the world inhabited by diverse ethnic groups experience with conflict. A number of countries in the Middle East with differences in ethnic groups and beliefs were hit by conflict and civil war. In other parts of the world, such as Kashmir, East Turkey (Uyghurstan), a number of countries in Africa, Myanmar, and others came up as examples. Even in Indonesia as a multi-ethnic country, with hundreds ethnic groups can experience with conflicts that have potential to create disharmony in the community. To avoid conflict, millennials need to maintain intercultural communication and have 
intercultural competence. Weda and Atmowardoyo (2018, p. 9) argue that as a large nation with a variety of cultures and languages, everyone needs to maintain good relations with others and is hoped to have intercultural competence in expressing ideas and thought with people from other cultures. This statement is vital to build harmony and social tolerance with the motto Bhinneka Tunggal Ika which means unity in diversity. This is in accordance with Wing-Wah Law and Wai-Chung Ho (2011, p. 371) whose focus their study on the study of the Chinese state, which states that throughout China's history, the ethical perfect of social harmony has played an critical part in reinforcing national solidarity, improving cohesion of the nation, and upgrade companionship with neighboring countries. To avoid conflict amongst people from different cultural backgrounds, intercultural communication is needed to build social harmony in a pluralist society.

One of the most important elements in the society is millennial generation. Millennial needs to be empowered to promote the importance of intercultural communication. The millennial generation as a generation that is IT literate and lives in the digital age needs to maintain intercultural communication with people from different cultures, in other harmony can be realized in society. Sharma $(2015$, p. 7$)$ states that the cornerstone to achieving social harmony lies in being really social which can be done by not as it were understanding one's needs and needs but moreover respecting others equally.

The purpose of this study is to examine the concepts and elements of millennials' perception on promoting intercultural communication to build social harmony. For the purposes of this study, intercultural communication amongst people from different ethnic groups is considered very vital in daily life to build social harmony.

\section{LITERATURE REVIEW}

\section{Millennials}

Millennials (born between 1982 and 1994) have been exposed to the explosion of online technology platforms since its emergence, as it has been incorporated into almost every aspect of their daily lives (Duffett, 2014, p. 499). Millennials in the daily lives using various technological devices and media to maintain communication to others. Internet and social media are currently potential to be main means to promote mutual understanding and intercultural communication in digital era.

The Grail report, published in 2011, illustrates the contrasts between each era, and the table 1, adjusted with extra discoveries from Horsaengchai and Mamedovaas cited in Chandler (2015, p. 16), summarize some of the important findings of the Grail report.

Table 1. Key Characteristics of Generations

\begin{tabular}{|l|l|l|l|l|}
\hline \multicolumn{1}{|c|}{ Group } & \multicolumn{1}{|c|}{ Baby Boomers } & Generation X & \multicolumn{1}{|c|}{ Generation Y } & Generation Z \\
\hline Name & Hippies and Yuppies & Latchkey kids & $\begin{array}{l}\text { Millennial } \\
\text { generation }\end{array}$ & Digital natives \\
\hline $\begin{array}{l}\text { Birth year } \\
\text { (approx. })^{*}\end{array}$ & 1945 to early 1960s & $\begin{array}{l}\text { early 1960s to } \\
\text { early 1980s }\end{array}$ & $\begin{array}{l}\text { early 1980s to } \\
\text { early 2000s }\end{array}$ & $\begin{array}{l}\text { early 2000s to } \\
\text { present day }\end{array}$ \\
\hline $\begin{array}{l}\text { Nurturing } \\
\text { Environment }\end{array}$ & $\begin{array}{l}\text { Increasingly stable } \\
\text { and optimistic. Post } \\
\text { WWII, widespread } \\
\text { government }\end{array}$ & $\begin{array}{l}\text { Trends towards } \\
\text { divorce, economic } \\
\text { uncertainty. New } \\
\text { technologies (e.g. }\end{array}$ & $\begin{array}{l}\text { Increasing } \\
\text { interregional and } \\
\text { intercommunity } \\
\text { conflicts. New }\end{array}$ & $\begin{array}{l}\text { Terrorism and } \\
\text { environmental } \\
\text { concerns. } \\
\text { Economic }\end{array}$ \\
\hline
\end{tabular}




\begin{tabular}{|l|l|l|l|l|}
\hline & $\begin{array}{l}\text { subsidies in postwar } \\
\text { housing and } \\
\text { education, increasing } \\
\text { affluence. } \\
\text { Rebuilding after } \\
\text { WWII. Women's } \\
\text { rights, civil rights } \\
\text { movement, protest } \\
\text { Vietnam war }\end{array}$ & $\begin{array}{l}\text { cable TV, video } \\
\text { games, home } \\
\text { computing), } \\
\text { Disco / hip-hop } \\
\text { culture, punks and } \\
\text { anarchy. }\end{array}$ & $\begin{array}{l}\text { technologies } \\
\text { moving at a rapid } \\
\text { pace (internet, } \\
\text { mobile phones, } \\
\text { instant } \\
\text { communication via } \\
\text { email and sms). }\end{array}$ & $\begin{array}{l}\text { llowdown Rapid } \\
\text { technological } \\
\text { growth - social } \\
\text { networking, } \\
\text { hacking, } \\
\text { programming }\end{array}$ \\
\hline Stereotypes & $\begin{array}{l}\text { huge consumers, } \\
\text { idealistic, } \\
\text { competitive }\end{array}$ & $\begin{array}{l}\text { individualists, } \\
\text { sceptical of } \\
\text { authority }\end{array}$ & $\begin{array}{l}\text { 'techcomfortable', } \\
\text { brand loyal, style- } \\
\text { conscious, } \\
\text { optimistic }\end{array}$ & $\begin{array}{l}\text { tech savvy, } \\
\text { globally } \\
\text { connected, } \\
\text { flexible and } \\
\text { open / tolerant of } \\
\text { diverse cultures }\end{array}$ \\
\hline
\end{tabular}

Generational categories as outlined in the Table 2 have been suspected of stereotyping across generations and it seems the focus remains on negative rather than positive impacts on each generation (Chandler, 2015, p. 16). Although Horsaengchai and Mamedova (2011) as authors acknowledge that such stereotypes can be stated unhelpful, categorizing some aspects that may arise in everyday life can help in promoting shared understanding across groups as well as provide people with a basis to understand and appreciate diversity in an organization and clear communication gaps (Chandler, 2015, p. 16).

The younger generation born after 1977 (Zickhur, 2011 as cited in Fructuoso, 2015, p. 51- 52) are called as Millennial Generation, Net Generation, IM Generation, Gamers Generation, Digital Natives, Digital Residents or Homo Zappiens (Pedró, 2006 as quoted in Fructuoso, 2015, pp. 51 52). Millennials are branded as self-assured, liberal, positive, open to change, more educated than the earlier generation, always linked, immersed in digital technology and social media, and embracing various modes of expressiveness (Pew Research Center, 2010 as quoted in Fructuoso (2015, pp. 51 - 52).

\section{Intercultural Communication}

Intercultural interactions always reveal that communicating objects in communication practices appear as subjects from certain cultures, which are agents of certain sociocultural communities (Malyuga, et. al., 2018, p. 566). Traditionally, the study of intercultural communication refers to the study of interactions between people from different cultures and the comparative study of cross-cultural communication patterns (Hua, 2014).

Individual strength and stability have been cited in various forms as vital traits for effective intercultural correspondents (Williams, 2005, p. 359). Ting-Toomey (as quoted in Williams, 2005, p. 359) writes that one of the key components for the success of intercultural communication is the capacity to manage psychological aspects. Williams (2005, p. 359) therefore adds that emotional flexibility to look failure, confusion, misunderstanding, and to work towards positive communications is recognized by many scholars and researchers as an vital component of effective intercultural communication skills.

\section{Social Harmony}

Mulyana (2012, p. 47) seems to state that specifically from the Indonesian point of view, being portion of the civilized world branded by understanding and harmony among religious believers is still exceptionally distant from reality because in Indonesia there are 
still many inter-ethnic problems as well as intolerance and hostility between religious communities depicted by various riots between tribes and religions that cause death in the community. As a multiethnic country, all Indonesian people need to maintain good understanding and tolerance to live in harmony as part of modern civilization on this planet. God finished this planet a lovely place to live in and sent his best creations like humans to live on this planet (Sharma, 2015, p. 5). He wants his men to live in this put with shared adore, regard and cooperation. All religious and cultural systems in the World be it Muslim, Zoroastrianism, Hinduism, Buddhism, Jainism, Sikhs and Christianity, etc. Since the beginning he has always preached for the right relationship between humans to build peace and harmony in social life (Sharma, 2015, p.5). Sharma $(2015$, p. 6) provides strategies to promote social harmony that can make people more social to one another. This can be completed at two stages: the institutional level and the personal level. At the institutional level, the next middle goals can be taken after to realize the ultimate goal of Social Harmony as shown in Table 2. At the personal level, it can be done by taking after certain simple recommendations which include: creating sympathy, social grouping for friendship, tolerance, mutual reinforcement, gaining allies, and bridge the gap.

Table 2. Illustrations of the means and ends of achieving relational well-being and social harmony in a society (Sharma, 2016, p. 6)

\begin{tabular}{|c|c|c|}
\hline Institutions & Intermediate goals & Final goal/end \\
\hline Family & $\begin{array}{l}\text { - Family cooperation and happiness establishment. } \\
\text { - Low separation rates, socially maintainable birth } \\
\text { rate. } \\
\text { - Effective household care for older followers. } \\
\text { - Gender co-operation inside and outside the } \\
\text { family etc. }\end{array}$ & \\
\hline $\begin{array}{l}\text { Nations and } \\
\text { Government }\end{array}$ & 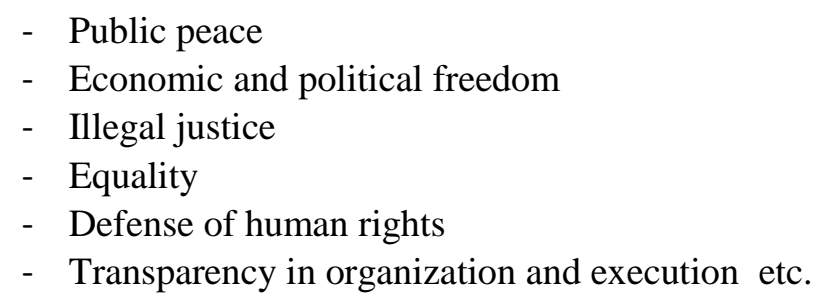 & \\
\hline Organizations & $\begin{array}{ll}\text { - } & \text { Broad distribution of property resources } \\
\text { - } & \text { Integration of trade and community life } \\
\text { - } & \text { Absence of determined obligation } \\
\text { - } & \text { High levels of family business/self-employment } \\
\text { - } & \text { Incentives for risk-sharing and coordinate } \\
& \text { budgetary connections } \\
\text { - } & \text { A week after week shared day off etc. }\end{array}$ & $\begin{array}{l}\text { 'Righteousness' and } \\
\text { Harmony in all relations } \\
\text { - } \text { respect for God } \\
\text { - love/empathy } \\
\text { - } \\
\text { equity, } \\
\text { reasonableness, }\end{array}$ \\
\hline $\begin{array}{l}\text { Community } \\
\text { and Neigh- } \\
\text { borhood }\end{array}$ & $\begin{array}{l}\text { - Community courts and other shapes of nearby } \\
\text { equity } \\
\text { - Widespread/universal information of what the } \\
\text { law says } \\
\text { - Wrongdoer reintegration into society after } \\
\text { discipline. } \\
\text { - - Understanding others issues and attempt to sort } \\
\text { out etc. }\end{array}$ & $\begin{array}{ll} & \text { parity } \\
\text { - } & \text { faithfulness } \\
\text { - } & \text { truth } \\
\text { - } & \text { forgiveness } \\
\text { - } & \text { trust } \\
\text { - } & \text { liberality } \\
\text { - } & \text { sympathy. }\end{array}$ \\
\hline
\end{tabular}


In Indonesian social and political life and practice, the Suharto government sought to 'harmonize' state-religious relations, after a period of unequal inter-religious conflict and increasing antagonism between government and Islam (mid 1960s to late 1970s) escalating. Concerns about stability (Porter, 2005, p. 62). Porter therefore advertises that as a culmination of these concerns, in 1978, the Minister of Religion Alamsjah issued a policy statement called 'three harmony (tri kerukunan)', which was an effort to redirect and guide spiritual life and most importantly of the three harmonies was the achievement of harmony between the state and religion, especially Islam. The purpose is to assist the government in building stability and national security by directing religious life to national development priorities. Good state-religious relations, determined, depend on the implementation of the Pancasila indoctrination course (P4) in society (Porter, 2005, p. 62).

\section{RESEARCH METHODS}

In order to answer the research objectives as previously stated, 42 questionnaires were distributed to graduate students and undergraduate students at Universitas Negeri Makassar, Indonesia. This study therefore employs a mixed-methods research design through the analysis of questionnaire and interview.

\section{Participants}

Participants in this present study were 42 English majors, 12 or $28.57 \%$ male and 30 or $71.43 \%$ female. There were 19 participants from English study program of Graduate Program, Universitas Negeri Makassar and there were 23 participants from English Department (English Literature Study Program, English Education, and Business English/D3 Program) of Universitas Negeri Makassar, Makassar Indonesia.

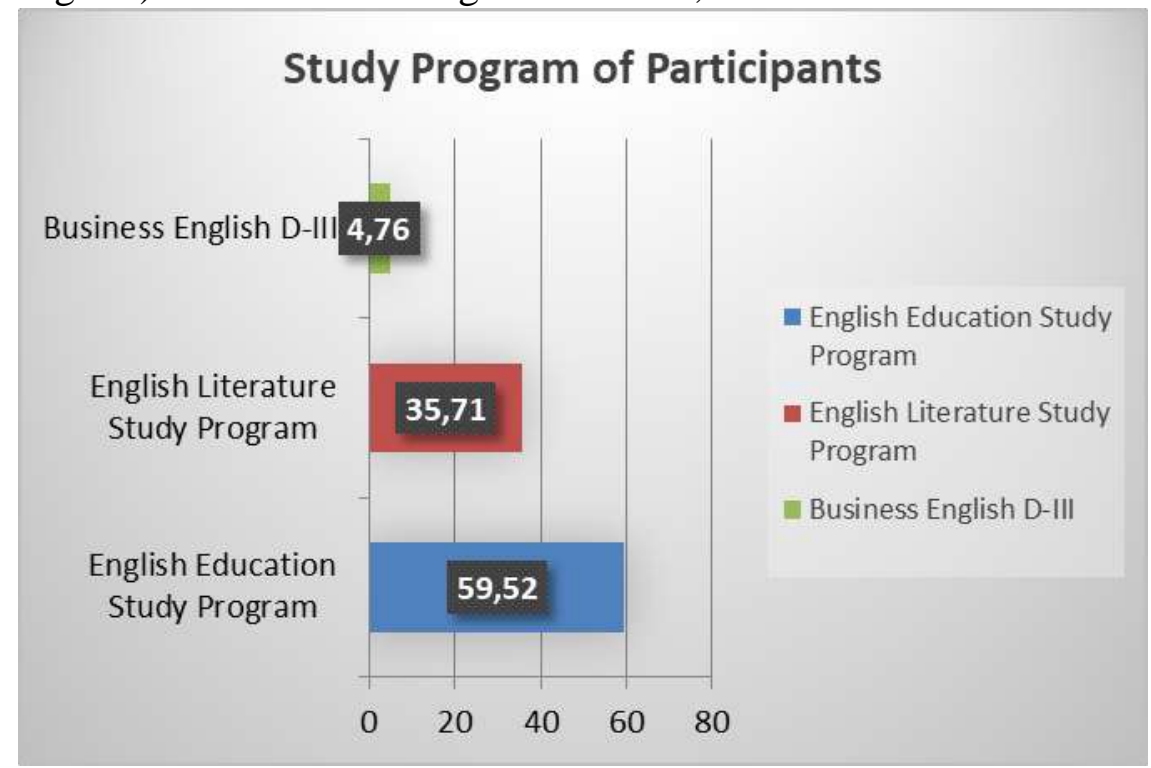

Chart. 1. Study Program of Participants

\section{Instruments and Procedures}

The instrument used to assess students' perceptions of how millennials promote intercultural communication to build social harmony. This instrument aims to explore students' perceptions in promoting intercultural communication. Data on student perceptions of intercultural communication was collected in January 2019 for students of the Department of English, Faculty of Language and Literature and students of English Education at Universitas Negeri Makassar. Students are asked to fill out a questionnaire 
consisting of 20 items. In this study, the participants were requested to rate their perceptions to test their perceptions of the promotion of intercultural communication on a 5-point scale where $1=$ Strongly Disagree; $2=$ Disagree; $3=$ Neutral; $4=$ Agree, and $5=$ Strongly Agree.

\section{Data Analysis}

Data were coded and analyzed using the Statistical Package of Social Sciences (SPSS) Statistics 9.0 showing the mean, Standard Deviation (SD), and percentage. Weights and rank are also revealed in the study.

\section{RESULTS AND DISCUSSION}

\section{Demographics of Participants}

The results of the study expose the demographic of participants as stated in table 2 . There were 30 female $(71.43 \%)$ and there were $12(28.57 \%)$ male. There were $23(54.76 \%)$ students from Undergraduate Program and there were 19 (45.24\%) students from Graduate Program Universitas Negeri Makassar. There were 25 (59.52\%) students from English Education Study Program, 15 (35.71\%) students from English Literature Study Program, and $2(4.76 \%)$ students from Business English (D3 Program) of Universitas Negeri Makassar.

Table 3. Demographics of Participants

\begin{tabular}{l|ll|c|c}
\hline Demographic Information & Frequency & Percentage \\
\hline Gender & 1. & Female & 30 & 71.43 \\
\hline & 2. & Male & 12 & 28.57 \\
\hline Degree & 1. & Undergraduate degree & 23 & 54.76 \\
\hline & 2. & Master's degree & 19 & 45.24 \\
\hline Study Program & 1. & English Education & 25 & 59.52 \\
\hline & 2. & English Literature \\
& Study Program & 15 & 35.71 \\
\hline & 3. & Business English (D3) & 2 & 4.76 \\
\hline
\end{tabular}

\section{Students' Perception on How Millennials PromoteSocial Harmony through Intercultural Communication}

Table 4. Percentages and rank of each of students' perception on how millenials promote social harmony through intercultural communication

\begin{tabular}{|c|c|c|c|c|c|c|c|c|c|}
\hline$\dot{\mathbf{z}}$ & Students' Perception & 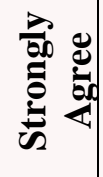 & 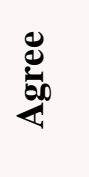 & 吾 & 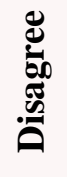 & 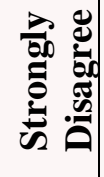 & 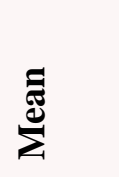 & $\begin{array}{l}\vec{E} \\
\frac{\vec{E}}{200} \\
\vec{E}\end{array}$ & 華 \\
\hline 1. & $\begin{array}{l}\text { Conflicts between } \\
\text { residents occur } \\
\text { because of a lack of } \\
\text { mutual understanding } \\
\text { among them. }\end{array}$ & 50.0 & 47.6 & 2.4 & 0 & 0 & 4.4762 & 97.6 & 1 \\
\hline 2. & $\begin{array}{l}\text { Intolerance occurs } \\
\text { between people from } \\
\text { different ethnic groups } \\
\text { because of the lack of }\end{array}$ & 31.0 & 52.4 & 14.3 & 2.4 & 0 & 4.1190 & 83.4 & 6 \\
\hline
\end{tabular}




\begin{tabular}{|c|c|c|c|c|c|c|c|c|c|}
\hline & $\begin{array}{l}\text { intercultural } \\
\text { communication links. }\end{array}$ & & & & & & & & \\
\hline 3. & $\begin{array}{l}\text { Awareness of cultural } \\
\text { differences can reduce } \\
\text { social conflict. }\end{array}$ & 59.5 & 26.2 & 14.3 & 0 & 0 & 4.4524 & 85.7 & 5 \\
\hline 4. & $\begin{array}{l}\text { Intercultural } \\
\text { communication needs } \\
\text { to be taught early in } \\
\text { school. }\end{array}$ & 42.9 & 47.6 & 9.5 & 0 & 0 & 4.3333 & 90.5 & 3 \\
\hline 5. & $\begin{array}{l}\text { Millennials need to } \\
\text { respect cultural } \\
\text { differences. }\end{array}$ & 66.7 & 28.6 & 4.8 & 0 & 0 & 4.6190 & 95.3 & 2 \\
\hline 6. & $\begin{array}{l}\text { Millennials need to } \\
\text { accept differences at a } \\
\text { meeting. }\end{array}$ & 45.2 & 52.4 & 2.4 & 0 & 0 & 4.4286 & 97.6 & 1 \\
\hline 7. & $\begin{array}{l}\text { Millennials love to } \\
\text { create social harmony. }\end{array}$ & 42.9 & 40.5 & 16.7 & 0 & 0 & 4.2619 & 83.4 & 6 \\
\hline 8. & $\begin{array}{l}\text { Intercultural } \\
\text { communication can } \\
\text { create social harmony. }\end{array}$ & 31.0 & 54.8 & 14.3 & 0 & 0 & 4.1667 & 85.8 & 4 \\
\hline 9. & $\begin{array}{l}\text { Millennials accept } \\
\text { differences in race, } \\
\text { religion, and ethnicity. }\end{array}$ & 38.1 & 26.2 & 31.0 & 4.8 & 0 & 3.9762 & 64.3 & 12 \\
\hline 10. & $\begin{array}{l}\text { Do not use your own } \\
\text { culture to assess the } \\
\text { culture of others from } \\
\text { different ethnic } \\
\text { groups. }\end{array}$ & 66.7 & 23.8 & 9.5 & 0 & 0 & 4.5714 & 90.5 & 3 \\
\hline 11. & $\begin{array}{l}\text { Millennials are able to } \\
\text { implement ideal } \\
\text { values from the } \\
\text { culture they have. }\end{array}$ & 28.6 & 38.1 & 28.6 & 4.8 & 0 & 3.9048 & 66.7 & 11 \\
\hline 12. & $\begin{array}{l}\text { The diversity of ethnic } \\
\text { groups in a society is } \\
\text { the main capital to } \\
\text { build a nation. }\end{array}$ & 33.3 & 47.6 & 14.3 & 4.8 & 0 & 4.0952 & 80.9 & 8 \\
\hline 13. & $\begin{array}{l}\text { The diversity of ethnic } \\
\text { groups in a society } \\
\text { triggers social } \\
\text { disharmony. }\end{array}$ & 11.9 & 38.1 & 19.0 & 26.2 & 4.8 & 3.2619 & 50 & 13 \\
\hline 14. & $\begin{array}{l}\text { Social disharmony can } \\
\text { be avoided through } \\
\text { intercultural } \\
\text { communication. }\end{array}$ & 23.8 & 52.4 & 21.4 & 2.4 & 0 & 3.9762 & 76.2 & 10 \\
\hline 15. & $\begin{array}{l}\text { Intercultural } \\
\text { communication can be } \\
\text { well established, if } \\
\text { each party } \\
\text { understands their } \\
\text { respective cultures. }\end{array}$ & 45.2 & 52.4 & 2.4 & 0 & 0 & 4.4286 & 97.6 & 1 \\
\hline 16. & $\begin{array}{l}\text { Intercultural } \\
\text { communication can be } \\
\text { well established, if }\end{array}$ & 54.8 & 40.5 & 4.8 & 0 & 0 & 4.5000 & 95.3 & 2 \\
\hline
\end{tabular}




\begin{tabular}{l|l|l|l|l|l|l|l|l|l}
\hline & $\begin{array}{l}\text { each party respects the } \\
\text { culture of others. }\end{array}$ & & & & & & & & \\
\hline 17. & $\begin{array}{l}\text { In intercultural } \\
\text { communication, non- } \\
\text { verbal language has } \\
\text { an important role. }\end{array}$ & 23.8 & 54.8 & 21.4 & 0 & 0 & 4.0238 & 78.6 & 9 \\
\hline 18. & $\begin{array}{l}\text { Visiting each other } \\
\text { between different } \\
\text { ethnic groups can } \\
\text { create social harmony. }\end{array}$ & 38.1 & 45.2 & 11.9 & 4.8 & 0 & 4.1667 & 83.2 & 7 \\
\hline 19. & $\begin{array}{l}\text { Being actively } \\
\text { involved in } \\
\text { organizations between } \\
\text { ethnic groups can } \\
\text { create social harmony }\end{array}$ & 35.7 & 45.2 & 16.7 & 2.4 & 0 & 4.1429 & 80.9 & 8 \\
\hline 20. & $\begin{array}{l}\text { Millennials do not } \\
\text { demean other people's } \\
\text { culture. }\end{array}$ & 28.6 & 47.6 & 19.0 & 4.8 & 0 & 4.0000 & 76.2 & 10 \\
\hline
\end{tabular}

The highest response for statement number 1 (Conflicts between residents occur because of a lack of mutual understanding among them.) was Strongly Agree with $50.0 \%$. The uppermost response for number 2 (Intolerance occurs between people from different ethnic groups because of the lack of intercultural communication links) was Agree with $52.4 \%$. The top response for statement number 3 (Awareness of cultural differences can reduce social conflict) was Strongly Agree with 59.5\%. The maximum response for number 4 (Intercultural communication needs to be taught early in school) was Strongly Agree with $42.9 \%$. The dominant response for number 5 (Millennials need to respect cultural differences) was Fairly Typical of Me with 56.7\%. The optimum response for number 6 (Millennials need to accept differences at a meeting) was Strongly Agree with $66.7 \%$. For statement number 7 (Millennials love to create social harmony) is a part of the target culture, and therefore it has a value as part of the learners' general education) was Strongly Agree with $42.9 \%$ and this percentage shows the highest score in this number. The response for number 8 (Intercultural communication can create social harmony) was Agree with 54.8\% which shows the maximum score. The response for statement number 9 (Millennials accept differences in race, religion, and ethnicity) was Strongly Agree with $38.1 \%$. The response for statement number 10 (Do not use your own culture to assess the culture of others from different ethnic groups) was Strongly Agree with 66.7\%. The response for statement number 11 (Millennials are able to implement ideal values from the culture they have) was Agree with 38.1\%. The response for statement number 12 (The diversity of ethnic groups in a society is the main capital to build a nation) was Agree with 47.6\%. The response for statement number 13 (The diversity of ethnic groups in a society triggers social disharmony) was Agree with $38.1 \%$. The response for statement number 14 (Social disharmony can be avoided through intercultural communication) was Agree with $52.4 \%$. The response for statement number 15 (Intercultural communication can be well established, if each party understands their respective cultures) was Agree with 52.4\%. The response for statement number 16 (Intercultural communication can be well established, if each party respects the culture of others) was Strongly Agree with 54.8\%. The response for number 17 (In intercultural communication, non-verbal language has an important role) was Agree with $54.8 \%$. The response for statement number 18 (Visiting each other between different ethnic groups can create social harmony) was Agree with 45.2 \%. The 
highest response for statement number 19 (Being actively involved in organizations between ethnic groups can create social harmony) was Agree with $45.2 \%$. The highest response for statement number 20 (Millennials do not demean other people's culture) Agree with 47.6\%.

The first rank of students' perception (millenials) on promoting intercultural communication to build harmony is statement number 1 (Conflicts between residents occur because of a lack of mutual understanding among them), statement number 6 (Millennials need to accept differences at a meeting), and statement number 15 (communication can be well established, if each party understands their respective cultures). This means that millenials as agent of change in democratic society need to implement and enhance shared understanding among individuals from dissimilar ethnic groups. They also need to accept differences in a wide range of meetings or discussions. The millenials are also recommended to understand other cultures to build social harmony in society.

The results indicate that millennials needs to respect cultural differences. This in keeping with Hernandez \& Kose (2012, p. 512) who argue that principals' understanding and skills relating to variety are important in leading varied schools and preparing all students for democratic and diverse society. Intercultural communication and cultural competence need to be taught early in school. Hernandez \& Kose (2012, p. 513) emphasize that cultural competence should be an important aspect of school principals' preparation and practice. The study also concludes that the millennials love social harmony. Weda and Atmowardoyo (2018, p. 9) state that the cross cultural competence (CCC) under the cross cultural understanding is a cornerstone to shape social harmony and harmony in multicultural society.

\section{What Do You Do during Sustaining Intercultural Communication to Individuals from other Ethnic Groups?}

The informants show a strong interest in maintaining intercultural communication. To achieve this, some informants gave a wide variety of invaluable comments as stated in the following table.

Table 5. Participants' perception on maintaining intercultural communication to people from other ethnic groups

\begin{tabular}{ll}
\hline Informant 1 & Respect for differences \\
\hline Informant 2 & Support each other and respect each other's opinions. \\
\hline Informant 4 & Respect each other. \\
\hline Informant 5 & Respect other people's culture. \\
\hline Informant 6 & Support each other in terms of kindness \\
\hline Informant 8 & Maintain good communication to build harmony. \\
\hline Informant 9 & $\begin{array}{l}\text { I will maintain good relationship with other people from different ethnic } \\
\text { groups. }\end{array}$ \\
\hline Informant 10 & Respect and help each other when others need. \\
\hline Informant 11 & $\begin{array}{l}\text { I agree that as a multicultural citizen, I respect opinions by not involving } \\
\text { inter-ethnic conflict. }\end{array}$ \\
\hline Informant 12 & $\begin{array}{l}\text { It is enough to respect what is religion, ethnic, and others' beliefs, and } \\
\text { each does not interfere with each other and respect the opinions of others. }\end{array}$ \\
\hline Informant 13 & Not excessive in joking. \\
\hline Informant 14 & Please help and establish friendship. \\
\hline Informant 15 & $\begin{array}{l}\text { I will always visit other people's homes that are ethnically different and } \\
\text { greet each other in order to create social harmony. }\end{array}$ \\
\hline Informant 16 & As little as possible stay away from differences. \\
\hline
\end{tabular}




\begin{tabular}{|c|c|}
\hline Informant 17 & $\begin{array}{l}\text { Share stories, try to ask questions politely, study through literature and get } \\
\text { along without bringing tribal superiority. }\end{array}$ \\
\hline Informant 18 & Hang out as politely as possible. \\
\hline Informant 19 & What I do is respect each other and create good communication. \\
\hline Informant 21 & $\begin{array}{l}\text { By maintaining communication and respecting and understanding each } \\
\text { other's culture. }\end{array}$ \\
\hline Informant 22 & $\begin{array}{l}\text { I use verbal and non-verbal languages as best as I can so as to create } \\
\text { harmony. }\end{array}$ \\
\hline Informant 23 & Shut up and observe and let the other person speak out. \\
\hline Informant 24 & $\begin{array}{l}\text { Try to understand what is being discussed. Besides that, respect the } \\
\text { person and show polite and friendly attitude during maintaining } \\
\text { communication. }\end{array}$ \\
\hline Informant 26 & $\begin{array}{l}\text { We must respect the culture of each ethnic group, establish good } \\
\text { communication, and put aside differences. }\end{array}$ \\
\hline Informant 27 & $\begin{array}{l}\text { Respecting the opinions of others and giving a good response to what is } \\
\text { said by the other person. }\end{array}$ \\
\hline Informant 28 & Respect for cultural diversity. \\
\hline Informant 29 & $\begin{array}{l}\text { Be active in responding and discussing with friends who have different } \\
\text { ethnicities and cultures. }\end{array}$ \\
\hline Informant 30 & Communicate without degrading other ethnicities. \\
\hline Informant 31 & $\begin{array}{l}\text { Cultivating a respectful attitude between cultures that is different from the } \\
\text { one we have in order to create a harmonious relationship between people. }\end{array}$ \\
\hline Informant 32 & I do so far is better understanding the differences. \\
\hline Informant 33 & Understand each other's culture so as not to demean other ethnicities. \\
\hline Informant 34 & I hope that solidarity is maintained. \\
\hline Informant 35 & $\begin{array}{l}\text { During maintaining communication, we should keep the words to be } \\
\text { conveyed so that other people from different ethnic groups are not } \\
\text { offended. }\end{array}$ \\
\hline Informant 36 & $\begin{array}{l}\text { As a young generation, we need to be actively involved in organizations } \\
\text { to carry out social activities. }\end{array}$ \\
\hline Informant 37 & $\begin{array}{l}\text { Appreciating customs, culture, and differences of opinion is the key to } \\
\text { building social harmony. Differences certainly exist, but respecting these } \\
\text { differences is a way to unite opinions, and establish good communication } \\
\text { between other ethnic groups can create harmony between different ethnic } \\
\text { groups. }\end{array}$ \\
\hline Informant 38 & $\begin{array}{l}\text { Studying their culture, respecting them, not verbally blaming or justifying } \\
\text { what is their tradition. }\end{array}$ \\
\hline Informant 39 & $\begin{array}{l}\text { Understand the habits, culture, and character of others and treat them } \\
\text { according to what they should be. }\end{array}$ \\
\hline Informant 40 & Introducing culture politely and without degrading other people's culture. \\
\hline Informant 41 & Respect each other's differences between different ethnic groups. \\
\hline Informant 42 & $\begin{array}{l}\text { I try to be neutral in speaking and respecting opinions expressed by } \\
\text { others. }\end{array}$ \\
\hline
\end{tabular}

Based on the above informants' comments, to keep a respectable intercultural communication to people from other ethnic groups, they maintain mutual respect and maintain intercultural communication based on mutual respect and understanding. Therefore, to maintain successful intercultural communication, individuals in the society need to be competent towards intercultural communication skills to other people from different ethnic groups. Williams (2005, p. 356) argues that exposure to numerous cultures was the greatest forecaster of intercultural communication skills. Mulyana (2012, p. 38) asserts that with regard to the tendencies that cultural differences will remain forever, 
theoretical knowledge and practical global guidelines on intercultural communication need to be taught to Indonesia people, including those who work in business, so that they are able to work and communicate cross-culturally in the twenty-first century.

\section{What Do You Expect from People from other Ethnic Groups in Maintaining Intercultural Communication to Build Social Harmony?}

The informants show a strong interest in maintaining intercultural communication to promote social harmony. To achieve this, some informants gave invaluable comments as stated in the following table.

Table 6. Participants' perception on building social harmony

\begin{tabular}{|c|c|}
\hline Informant 1 & Respect and maintain differences without degrading each other. \\
\hline Informant 2 & $\begin{array}{l}\text { I really hope for mutual respect for each other's differences by paying } \\
\text { attention on the values of Pancasila and Bhinneka Tunggal Ika (Unity in } \\
\text { Diversity). }\end{array}$ \\
\hline Informant 4 & $\begin{array}{l}\text { I hope for mutual respect with each other's differences so as to create } \\
\text { social hamony. }\end{array}$ \\
\hline Informant 5 & $\begin{array}{l}\text { I hope for the need for mutual respect between two different ethnic } \\
\text { groups. }\end{array}$ \\
\hline Informant 6 & $\begin{array}{l}\text { Love each other and respect other people even they are from different } \\
\text { religions, races, and ethnicities. }\end{array}$ \\
\hline Informant 8 & Give positive effect even the people are from different ethnic group. \\
\hline Informant 9 & $\begin{array}{l}\text { I very much hope to maintain good cooperation and build intact social } \\
\text { relation. }\end{array}$ \\
\hline Informant 10 & Friendly and not arrogant. \\
\hline Informant 11 & $\begin{array}{l}\text { The point will be very good if we respect the opinions, tribes, beliefs that } \\
\text { each person has. }\end{array}$ \\
\hline Informant 12 & $\begin{array}{l}\text { Uphold the values of Pancasila, interpret deeply and implement them in } \\
\text { social life and society. }\end{array}$ \\
\hline Informant 13 & Intercultural knowledge \\
\hline Informant 14 & Respect each other's cultures. \\
\hline Informant 15 & Friendly and mutual respect. \\
\hline Informant 16 & Knowledge of tolerance between ethnic groups. \\
\hline Informant 17 & $\begin{array}{l}\text { Reducing conflict, miscommunication or misunderstanding so that } \\
\text { brotherhood is established. }\end{array}$ \\
\hline Informant 18 & Eternal peace. \\
\hline Informant 19 & What we hope for is the realization of peace among each other. \\
\hline Informant 20 & Respect each other. \\
\hline Informant 21 & $\begin{array}{l}\text { Understand each other about their differences because of differences that } \\
\text { can unite individuals or groups. }\end{array}$ \\
\hline Informant 22 & Respect and accept differences in views and opinions. \\
\hline Informant 23 & Take and sort out and try to combine with our own culture. \\
\hline Informant 24 & $\begin{array}{l}\text { My hope is that other people from different ethnic groups can also } \\
\text { appreciate the culture that I have. }\end{array}$ \\
\hline Informant 26 & $\begin{array}{l}\text { I hope that communication can still run well. Mutual respect for } \\
\text { differences is the key to creating social harmony. }\end{array}$ \\
\hline Informant 27 & $\begin{array}{l}\text { Be able to provide an understanding of cross-cultural communication and } \\
\text { be able to accept the differences. }\end{array}$ \\
\hline Informant 28 & Mutual understand and respect each other. \\
\hline Informant 29 & $\begin{array}{l}\text { I hope they understand the differences, do not vilify groups of different } \\
\text { ethnic groups, and hope they do not consider their ethnicity to be the right }\end{array}$ \\
\hline
\end{tabular}




\begin{tabular}{ll}
\hline & one in order to maintain harmony in friendship. \\
\hline Informant 30 & Respect each other. \\
\hline Informant 31 & $\begin{array}{l}\text { They are able to appreciate the differences between cultures in society } \\
\text { without highlighting that their culture is the best compared to other } \\
\text { cultures. }\end{array}$ \\
\hline Informant 32 & Inter-cultural understanding is needed. \\
\hline Informant 33 & Creating a culture of mutual respect and developing a broader perspective. \\
\hline Informant 34 & I hope tolerance will be maintained. \\
\hline Informant 35 & $\begin{array}{l}\text { Trying to respect differences and maintain good communication, and } \\
\text { provide education so that others can understand the culture we have. }\end{array}$ \\
\hline Informant 36 & $\begin{array}{l}\text { We can carry out activities related to national culture. } \\
\text { Informant 37 main purpose of intercultural communication is to create harmony } \\
\text { between nations and countries in accordance with our country's "Bhinneka } \\
\text { Tunggal Ika" (Unity in Diversity). Indonesia consists of several races, } \\
\text { ethnicities, and cultures, therefore intercultural communication is very } \\
\text { necessary to achieve harmony, unity and cooperation among nations. }\end{array}$ \\
\hline Informant 38 & $\begin{array}{l}\text { Do not force between different cultures/habits. } \\
\text { Informant 39 }\end{array}$ \\
\hline Informant 40 & $\begin{array}{l}\text { Maintain the characteristics of one's own culture and still respect the } \\
\text { culture of others. }\end{array}$ \\
\hline Informant 41 & $\begin{array}{l}\text { I hope that other people can accept diversity and the differences that } \\
\text { occur. }\end{array}$ \\
\hline Informant 42 & $\begin{array}{l}\text { When communication takes place, other ethnic groups are expected to } \\
\text { respect other ethnic groups as well, and use polite language and not } \\
\text { offend others. }\end{array}$ \\
\hline
\end{tabular}

Based upon the informants' comments, the key to build social harmony in the multi ethnic society is accepting diversity and difference. Diversity and difference occur because there are lots of cultures in our planet and community.

To create harmony and tolerance within the multi-ethnic nations, cross-cultural competence (CCC) gets to be a imperative perspective in protecting cross-cultural communication (Weda \& Atmowardoyo, 2018, p. 9). The capacity to comprehend other cultures, in fact, is not as it were imperative at the interpersonal level but moreover at the universal one (Mulyana, 2012 as cited in Weda \& Atmowardoyo, 2018, p. 9). Mulyana subsequently upgrades that history uncovered that a few clashes and wars between nations are due to disappointments or troubles in increasing in value and understanding other cultures.

\section{CONCLUSION}

The present study reports on students' perception on promoting social harmony through intercultural communication in Indonesia as a multi-ethnic country. The study about appears that millennial as one of the potential elements to preserve intercultural communication to build social harmony in multi-ethnic society must be maintained. Resistance, shared understanding, shared regard, not belittling individuals from distinctive ethnic bunches, etc. are positive behaviors which ought to be advanced in multi-ethnic society. Subsequently, stereotypes and inclusive behaviors ended up imperative in building social agreement and peace in a multi ethnic country.

Social concordance is an perfect dream in life. Millenials as operator of alter is required to actualize and upgrade shared understanding among individuals from different ethnic bunches. Tolerating contrasts in a wide extend of social live could be a key 
worldview in line with understanding other societies to construct social agreement in society. For all intents and purposes, individuals ought to keep up common regard and keep up intercultural communication based on shared regard and understanding. Crosscultural competence gets to be a foremost in keeping up the case. to a few clashes and combats between nations are due to disappointments or difficulties.

The implication of the present study is to promote social harmony in a multi-ethnic society, cross cultural competence and intercultural communication are primary capital among Indonesian generation, especially for millennial in social lives.

\section{REFERENCES}

Chandler, Nick. (2015). Millennials, Entrepreneurs and the Hungarian Workplace of the Future: The Preliminary Findings of a Pilot Study. VEZETÉSTUDOMÁNY, XLVI. ÉVF. 2015. 11. SZÁM / ISSN 0133-0179.

Duffett, Rodney Graeme. (2015). Facebook Advertising's Influence on Intention-toPurchase and Purchase amongst Millennials", Internet Research, Vol. 25 Issue: 4, pp. 498-526, https:// doi.org/10.1108/IntR-01-2014-0020.

Fructuoso, Ingrid Noguera. (2015). How Millennials Are Changing the Way We Learn: The State of the Art of ICT Integration in Education. RIED, v. 18: 1, 2015, pp. 45 - 65.

Hernandez, Frank \& Kose, Brad W. (2012). The Developmental Model of Intercultural Sensitivity: A Tool for Understanding Principals' Cultural Competence. Education and Urban Society, 44(4), pp. 512-530.

Hua, Zhu. (2014). Exploring intercultural communication: Language in action. New York: Routledge.

Malyuga, Elena N; Krouglov, Alex \& Tomalin, Barry. (2018). Linguo-cultural competence as a cornerstone of translators' performance in the domain of intercultural business communication. XLinguae, Volume 11, Issue 2, April 2018, pp. 566 - 582.

Porter, Donald J. (2005). Managing Politics and Islam in Indonesia. London: Taylor \& Francis.

Sharma, Manisha. (2015). Social Harmony for Being Social. Global Journal of Human Social Science, Volume XV, Issue VI, Version I, pp.

Wing-Wah Law \& Wai-Chung Ho. (2011). Music Education in China: In Search of Social Harmony and Chinese Nationalism. British Journal of Music Education, Volume 28, Issue 03, November 2011, pp. $371-388$.

Weda, Sukardi \& Atmowardoyo, Haryanto. (2018). Cross - Cultural Competence (CCC) and Cross - Cultural Understanding (CCU) in Multicultural Education in the EFL Classroom. English as an International Language Journal, Volume 13, Issue 2.2, December 2018, pp. 9 - 31 .

Williams, Tracy Rundstrom. (2005). Exploring the Impact of Study Abroad on Students' Intercultural Communication Skills: Adaptability and Sensitivity. Journal of Studies in International Education, Vol. 9 No. 4, Winter 2005, pp. 356-371. 